\title{
Pengaruh Pemberian Employee Stock Option Plan (ESOP) pada Kinerja Perusahaan dan Implikasinya Terhadap Nilai Perusahaan
}

\author{
Ni Wayan Dea Dharmala ${ }^{1}$ \\ Ni Gusti Putu Wirawati \\ ${ }^{1,2}$ Fakultas Ekonomi dan Bisnis Universitas Udayana (Unud), Bali, Indonesia \\ e-mail: deadharmala@gmail.com
}

\begin{abstract}
ABSTRAK
Perusahaan merupakan kontrak antara pemilik perusahaan (prinsipal) dan manajemen (agen) yang disebut sebagai hubungan keagenan. Dalam hubungan ini, sering kali terdapat benturan kepentingan. Salah satu cara prinsipal untuk meminimalisir perbedaan kepentingan adalah dengan memberikan kompensasi kepada karyawan berupa program kepemilikan saham (ESOP). Penelitian ini bertujuan untuk mengetahui pengaruh pemberian ESOP pada kinerja perusahaan dan implikasinya terhadap nilai perusahaan.Penelitian ini dilakukan pada perusahaan yang terdaftar di BEI dan mengadopsi ESOP pada tahun 2013 2017. Sampel yang diperoleh berdasarkan metode purposive sampling adalah sebanyak 48 amatan. Pengumpulan data menggunakan metode observasi non partisipan. Teknik analisis data yang digunakan adalah analisis jalur. Hasil penelitian menunjukkan bahwa ESOP berpengaruh positif pada kinerja perusahaan, kinerja perusahaan berpengaruh positif pada nilai perusahaan, ESOP tidak berpengaruh pada nilai perusahaan, dan ESOP berpengaruh pada nilai perusahaan melalui kinerja perusahaan.
\end{abstract}

Kata Kunci: Employee stock option plan, kinerja perusahaan, nilai perusahaan

\begin{abstract}
The company is a contract between the owner of the company (principal) and management (agent) which is called the agency relationship. In this connection, there is often a conflict of interest. One of the principal ways to minimize differences in interests is to provide compensation to employees in the form of a share ownership program (ESOP). This study aims to determine the effect of giving ESOP on company performance and its implications for firm value. Samples obtained based on the purposive sampling method are 48 observations. Data collection uses non-participant observation methods. The data analysis technique used is path analysis. The results showed that ESOP had a positive effect on company performance, company performance had a positive effect on company value, ESOP had no effect on company value, and ESOP had an effect on firm value through company performance.

Keywords: Employee stock option plan, company performance, company value
\end{abstract}

\section{PENDAHULUAN}

Perusahaan merupakan suatu organisasi yang terdiri atas sekelompok orang yang bekerja untuk mencapai suatu tujuan. Tujuan jangka pendek perusahaan adalah mendapatkan laba, sedangkan tujuan jangka panjangnya adalah meningkatkan nilai perusahaan. Nilai perusahaan sangat penting dikarenakan dengan nilai 
perusahaan yang tinggi, akan diikuti oleh tingginya kemakmuran pemegang saham (Brigham dan Gapenski, 1996). Nilai perusahaan pada dasarnya diukur dari beberapa aspek salah satunya adalah harga pasar saham perusahaan, karena harga pasar saham perusahaan mencerminkan penilaian investor atas keseluruhan ekuitas yang dimiliki (Wahyudi dan Pawestri, 2006).

Perusahaan juga dipandang sebagai kontrak antara pemilik perusahaan sebagai prinsipal dan manajemen sebagai agen. Hal ini disebut dengan hubungan keagenan. Hubungan keagenan dinyatakan dalam teori keagenan. Manajemen adalah pihak yang dikontrak oleh pemilik untuk melakukan suatu jasa atas nama pemilik serta membuat keputusan yang terbaik bagi pemilik. Oleh karena itu, pihak manajemen wajib mempertanggungjawabkan semua pekerjaannya kepada pemilik. Jika agen (manajemen) dan prinsipal (pemilik) memiliki tujuan yang sama untuk meningkatkan nilai perusahaan, maka diyakini agen akan bertindak dengan cara yang sesuai dengan kepentingan prinsipal. Namun, pada kenyataannya sering kali terdapat pertentangan dan benturan kepentingan antara prinsipal dan agen yang disebut dengan masalah keagenan atau agency problem.

Agency problem tersebut seringkali disebabkan karena adanya asimetri informasi antara prinsipal dan agen. Asimetri informasi adalah ketidakseimbangan informasi yang dimiliki oleh agen dan prinsipal dimana manajemen selaku agen yang mengelola perusahaan cenderung memiliki informasi yang lebih banyak dibandingkan dengan pemilik (prinsipal). Hal ini disebabkan karena manajemen terlibat secara langsung dalam kegiatan operasional perusahaan. 
Dampak dari asimetri informasi ini adalah pencapaian kinerja perusahaan yang dapat terganggu dan juga dapat menyebabkan konflik kepentingan dimana pemilik perusahaan akan lebih mengutamakan peningkatan laba perusahaan dan mengabaikan keinginan manajemen sebagai pengelola (Eisenhardt, 1989). Sedangkan manajemen yang ditunjuk pemilik untuk mengelola perusahaan dapat melakukan tindakan yang menguntungkan dirinya sendiri dan mengorbankan kepentingan pemilik dengan kewenangan yang dimilikinya (Putri dan Nasir, 2006). Agency problem tersebut dapat menghambat kinerja perusahaan dalam memaksimalkan nilai perusahaan, maka prinsipal dapat mengambil langkah untuk menanggulangi masalah tersebut. Salah satu cara prinsipal untuk meminimalisir perbedaan kepentingan adalah dengan memberikan kompensasi kepada karyawan.

Kompensasi adalah setiap bentuk penghargaan yang diberikan kepada karyawan sebagai balas jasa atas kontribusi yang mereka berikan kepada perusahaan (Panggabean, 2004:75). Adanya pemberian kompensasi diharapkan dapat mengurangi konflik kepentingan pribadi antara agen dan prinsipal. Salah satu jenis kompensasi yang diberikan oleh perusahaan kepada karyawan berupa program kepemilikan saham (Employee Stock Ownership Plan).

Program ESOP adalah program kepemilikan saham kepada karyawan atas saham perusahaan yang diharapkan dapat meningkatkan rasa memiliki dari karyawan tersebut (Herdinata, 2012). Program ESOP dapat dilaksanakan melalui beberapa pendekatan, yaitu pembelian saham perusahaan, pemberian saham dalam bentuk bonus, pemberian opsi saham karyawan, dan beberapa pendekatan lainnya (Astika, 2012). Program ESOP diharapkan dapat mengatasi agency 
problem karena Program ESOP dapat mensejajarkan kepentingan antara prinsipal dan agen. Dengan menempatkan karyawan perusahaan sebagai agen dan juga prinsipal, diharapkan mereka lebih mengutamakan kepentingan perusahaan.

Opsi yang melibatkan seluruh karyawan diharapkan dapat menjadi suatu motivator yang lebih efektif untuk meningkatkan kinerja perusahaan dibandingan suatu bonus kas. Karena tidak seperti kas, opsi terus menerus berlaku sebagai suatu insentif yang baik bagi karyawan setelah mereka diberikan opsi, karena nilai sebenarnya akan ditentukan dengan kinerja perusahaan dimasa yang akan datang. Kinerja karyawan yang meningkat akan berdampak pada meningkatnya kinerja perusahaan.

Kinerja perusahaan merupakan hal yang diperhatikan investor untuk menilai kondisi perusahaan di masa kini dan juga prospek perusahaan di masa depan. Kinerja perusahaan pada penelitian ini diukur dengan menggunakan salah satu rasio profitabilitas yaitu Return On Assets (ROA). ROA berfungsi untuk mengukur efektivitas perusahaan dalam menghasilkan laba dengan memanfaatkan aktiva yang dimilikinya.

Kinerja perusahaan yang baik sebagai akibat dari adanya ESOP akan berpengaruh pada nilai perusahaan. semakin baik nilai perusahaan, maka akan meningkatkan kemakmuran pemilik dan menarik investor berinvestasi. Indikator yang digunakan pada penelitian ini untuk menggambarkan nilai perusahaan adalah menggunakan Rasio Tobin's $Q$. Rasio ini dapat memberikan informasi paling baik, karena rasio ini memasukkan semua unsur hutang dan modal saham perusahaan, tidak hanya saham biasa saja dan tidak hanya ekuitas perusahaan 
yang dimasukkan namun seluruh aset perusahaan.Dengan memasukkan seluruh aset perusahaan, hal ini berarti perusahaan tidak hanya terfokus pada satu tipe investor saja yaitu investor dalam bentuk saham tetapi juga untuk kreditur karena sumber pembiayaan operasional perusahaan bukan hanya dari ekuitasnya saja tetapi juga dari pinjaman yang diberikan oleh kreditur (Sukamulja, 2002).

Nilai perusahaan dapat dilihat dari harga pasar saham perusahaan. Fluktuasi harga saham yang terjadi pada perusahaan akan berdampak pula pada nilai perusahaan itu sendiri. Fenomena fluktuasi harga saham pada perusahaan yang mengadopsi ESOP pada tahun 2013-2017 ditunjukkan pada Tabel 1 berikut.

Tabel 1.

Fluktuasi Closing Price Tiga Perusahaan yang Terdaftar di BEI dan Mengadopsi ESOP pada tahun 2013-2017 (Disajikan dalam Rupiah per Lembar Saham)

\begin{tabular}{cllllll}
\hline \multirow{2}{*}{ No } & \multirow{2}{*}{ Perusahaan } & 2013 & 2014 & 2015 & 2016 & 2017 \\
\hline 1 & AKRA & 4375 & 4120 & 7175 & 6000 & 6350 \\
2 & BNGA & 845 & 595 & 835 & 920 & 1350 \\
3 & BCAP & 1340 & 995 & 1685 & 1480 & 1560 \\
\hline
\end{tabular}

Berdasarkan Tabel 1 dapat diketahui bahwa terjadi fluktuasi harga saham pada beberapa perusahaan yang menerbitkan ESOP. Salah satu perusahaan yang mengalami fluktuasi closing price yang cukup tajam yaitu PT. AKR Corporindo (AKRA) pada tahun 2013 hingga 2014 perusahaan tersebut mengalami penurunan harga saham yaitu dari tahun 2013 sebesar Rp 4.375, pada tahun 2014 menurun menjadi Rp 4.120, dan pada 2015 melonjak menjadi Rp 7.175 per lembar saham. Namun pada tahun 2016 dan 2017 harga saham perusahan tersebut mengalami penurunan dibandingkan harga saham tahun 2015, yaitu pada tahun 2016 sebesar Rp 6.000, dan tahun 2017 sebesar Rp 6.350. Begitu pula dengan harga saham 
Ni Wayan Dea Darmala dan Ni Gusti Putu Wirawati. Pengaruh ...

perusahaan lain yang juga mengalami kenaikan maupun penurunan selama lima tahun terakhir.

Program kepemilikan saham atau ESOP diharapkan akan berdampak pada peningkatan kinerja dan loyalitas karyawan kepada perusahaan, sehingga dengan peningkatan kinerja karyawan maka diharapkan akan berdampak pada nilai perusahaan, yang dicerminkan dengan peningkatan harga saham perusahaan. Namun pada fenomena fluktuasi harga saham pada Tabel 1, diketahui bahwa perusahaan yang mengadopsi ESOP masih banyak yang mengalami penurunan harga saham sehingga fenomena ESOP terhadap nilai perusahaan ini menarik untuk diteliti lebih lanjut.

Penelitian mengenai pengaruh ESOP pada kinerja perusahaan telah banyak dilakukan. Penelitian yang dilakukan oleh Borstadt et al., (1995) menemukan bahwa tidak adanya peningkatan kinerja perusahaan yang mengadopsi ESOP, yang diproxikan dengan NPM, ROA, ROE, dan TAT. Hal tersebut juga sejalan dengan penelitian yang dilakukan oleh Anwar dan Baridwan (2006), Poornima et al., (2015), Bacha et al., (2009) dan Yeo et al., (1999) yang mengemukakan bahwa ESOP tidak mampu meningkatkan kinerja keuangan perusahaan.Namun, penelitian yang dilakukan oleh Ngambi dan Oloume (2013), (Astika, 2005), Han dan Shen (2007), dan Pugh et al., (2000) menunjukkan hasil yang berbeda, yaitu perusahaan yang melaksanakan ESOP memiliki kinerja yang lebih tinggi dibandingkan yang tidak melaksanakan ESOP. Hal ini sejalan dengan penelitian yang dilakukan olehSesil et al., (2002) dan Iqbal dan Hamid (2000) yang menemukan bahwa ESOP berpengaruh terhadap kinerja perusahaan. 
Penelitian mengenai kinerja perusahaan terhadap nilai perusahaan juga telah banyak diteliti. Diantaranya adalah penelitian yang dilakukan oleh Susilowati (2011) dan Herawati (2013) yang menemukan bahwa variabel ROA berpengaruh negatif terhadap nilai perusahaan. Hal tersebut sejalan dengan penelitian yang dilakukan oleh Triagustina dkk., (2012) yang menemukan bahwa ROA berpengaruh negatif pada nilai perusahaan. Sedangkan, penelitian yang dilakukan oleh Prapaska dan Mutmainah (2012), Anzalina dan Rustam (2013), dan Yuniasih dan Wirakusuma (2009) menemukan hasil yang berbeda, yaitu kinerja perusahaan berpengaruh positif terhadap nilai perusahaan. Hal ini sejalan dengan penelitian yang dilakukan oleh Ulupui (2007), Nurhayati (2013) dan Hermuningsih (2013) yang menyatakan bahwa ROA berpengaruh positif terhadap nilai perusahaan

Penelitian mengenai ESOP terhadap nilai perusahaan juga telah banyak dilakukan. Penelitian yang dilakukan oleh Menurut Letlora (2012) informasi pelaksanaan ESOP ditanggapi positif melalui perubahan harga pasar saham. Hal ini sejalan dengan penelitian yang dilakukan oleh Aribawa (2016) yang menyatakan bahwa ESOP berpengaruh terhadap EVA yang merupakan tolak ukur dari nilai perusahaaan. Namun penelitian yang dilakukan oleh Qureyta (2016) menunjukkan hasil yang berbeda, yaitu PBV yang merupakan pengukuran nilai perusahaan sesudah penerapan ESOP tidak lebih baik daripada sebelum penerapan ESOP. Hal ini sejalan dengan penelitian yang dilakukan oleh Setyaningrum (2012) yang menemukan bahwa tidak adanya pengaruh 
pengadopsian ESOP terhadap PBV perusahaan sebelum pengadopsian ESOP dan sesudah pengadopsian ESOP.

Perusahaan dipandang sebagai kontrak antara pemilik perusahaaan sebagai prinsipal dan manajemen sebagai agen. Hal ini disebut dengan hubungan keagenan, yang dimana dinyatakan dalam teori keagenan. Jika agen (manajemen) dan prinsipal (pemilik) memiliki tujuan yang sama untuk meningkatkan nilai perusahaan, maka diyakini agen akan bertindak dengan cara yang sesuai dengan kepentingan prinsipal. Namun, pada kenyataannya sering kali terdapat pertentangan dan benturan kepentingan antara prinsipal dan agen. Adanya benturan kepentingan tersebut seringkali disebabkan karena adanya asimetri informasi antara prinsipal dan agen.

Asimetri informasi adalah ketidakseimbangan informasi yang dimiliki oleh agen dan prinsipal dimana manajemen selaku agen yang mengelola perusahaan cenderung memiliki informasi yang lebih banyak dibandingkan dengan pemilik (prinsipal). Dampak dari asimetri informasi ini adalah pencapaian kinerja perusahaan yang dapat terganggu. Oleh sebab itu, salah satu cara untuk mengatasi hal tersebut adalah dengan program kepemilikan saham oleh karyawan atau disebut ESOP. Dengan adanya ESOP karyawan akan memiliki rasa sense of belonging sehingga akan termotivasi untuk meningkatkan kinerjanya. Peningkatan kinerja karyawan akan berdampak pada peningkatan kinerja perusahaan.

Adapun penelitian sebelumnya yang dilakukan oleh Ngambi dan Oloume (2013), Astika (2005), Han dan Shen (2007), dan Pugh et al., (2000) menyatakan bahwa perusahaan yang melaksanakan ESOP memiliki kinerja yang lebih tinggi 
dibandingkan yang tidak melaksanakan ESOP. Hal ini sejalan dengan penelitian yang dilakukan oleh Sesil et al., (2002) dan Iqbal dan Hamid (2000) yang menemukan bahwa ESOP berpengaruh terhadap kinerja perusahaan. Sehingga, berdasarkan uraian tersebut, maka rumusan hipotesis yang dapat diajukan dalam penelitian ini:

$\mathrm{H}_{1}$ : ESOP berpengaruh positif pada kinerja perusahaan.

Kinerja perusahaan merupakan aspek penting yang dilihat oleh para investor untuk menilai kondisi perusahaan di masa kini dan juga prospek perusahaan di masa depan. Investor yang ingin menanamkan sahamnya seringkali melihat kinerja perusahaan sebagai pertimbangan dalam memutuskan dana yang diinvestasikan. Apabila kinerja perusahaan dilihat buruk, maka investor enggan untuk menginvestasikan dananya.

Dengan adanya program ESOP, agen tidak hanya bertindak sebagai pengelola perusahaan namun juga sebagai pemilik perusahaan. Program ESOP akan memberikan sense of belonging kepada karyawan sehingga akan meningkatkan komitmennya pada perusahaan.Kinerja perusahaan yang baik sebagai akibat dari adanya ESOP akan berpengaruh pada nilai perusahaan. semakin baik nilai perusahaan, maka akan meningkatkan kemakmuran pemilik dan menarik investor berinvestasi.

Adapun penelitian sebelumnya yang dilakukan oleh Prapaska dan Mutmainah (2012), Anzalina dan Rustam (2013), dan Yuniasih dan Wirakusuma, (2009) menemukan bahwa kinerja perusahaan berpengaruh positif terhadap nilai perusahaan. Hal ini sejalan dengan penelitian yang dilakukan oleh Ulupui (2007), 
Nurhayati (2013), dan Hermuningsih (2013) yang menyatakan bahwa ROA berpengaruh positif terhadap nilai perusahaan. Berdasarkan uraian tersebut, maka rumusan hipotesis yang dapat diajukan dalam penelitian ini:

$\mathrm{H}_{2}$ : Kinerja perusahaan berpengaruh positif pada nilai perusahaan.

Nilai perusahaan adalah nilai jual perusahaan atau nilai tumbuh bagi pemegang sahamRachmawati dan Triatmoko (2007). Nilai perusahaan sangat penting karena dengan nilai perusahaan yang tinggi, akan diikuti oleh tingginya kemakmuran pemegang saham. Nilai perusahaan yang tinggi akan membuat pasar percaya tidak hanya pada kinerja perusahaan, tetapi juga pada prospek perusahaan di masa depan. Fama (1978) menyatakan bahwa nilai perusahaan akan tercermin dari harga saham.

ESOP merupakan suatu program perusahaan yang memungkinkan para karyawan untuk turut serta memiliki saham dari perusahaan tempat mereka bekerja. Penerapan ESOP dapat menumbuhkan rasa memiliki terhadap perusahaan diantara para karyawan sehingga karyawan akan termotivasi dalam bekerja. Oleh sebab itu, ESOP akan dipandang oleh investor sebagai faktor yang dapat meningkatkan nilai perusahaan. Sehingga, ketika perusahaan mengumumkan ESOP, pengumuman tersebut akan di reaksi positif oleh investor karena dianggap sebagai kabar baik (good news).

Menurut Letlora (2012) informasi pelaksanaan ESOP ditanggapi positif melalui perubahan harga pasar saham. Hal ini sejalan dengan penelitian yang dilakukan oleh Aribawa (2016) yang menyatakan bahwa ESOP berpengaruh 
terhadap EVA yang merupakan tolak ukur dari nilai perusahaaan. Berdasarkan uraian tersebut, maka rumusan hipotesis yang dapat diajukan dalam penelitian ini: $\mathrm{H}_{3}$ : ESOP berpengaruh positif pada nilai perusahaan.

Biaya keagenan (agency cost) adalah biaya yang dikeluarkan prinsipal untuk mengatur dan mengawasi kinerja agen sehingga agen bekerja untuk kepentingan perusahaan.Untuk mengurangi agency cost, principal dapat menempuh beberapa mekanisme yaitu melalui program kepemilikan saham perusahaan bagi karyawan.ESOP merupakan salah satu cara untuk mengurangi konflik keagenan, karena dengan adanya ESOP karyawan mendapatkan kesempatan untuk memiliki saham perusahaan, sehingga karyawan akan termotivasi untuk memaksimalkan potensinya dalam meningkatkan kinerja perusahaan, karena kinerja perusahaan yang meningkat akan berdampak pada keuntungan yang didapatkan dari ESOP.

Perusahaan dengan kinerja keuangan yang baik, tentunya akan diminati oleh investor. Kinerja perusahaan merupakan hal yang diperhatikan investor untuk menilai kondisi perusahaan di masa kini dan juga prospek perusahaan di masa depan. Kinerja perusahaan yang baik akan membuat investor percaya dan menanamkan modalnya pada perusahaan. Semakin banyak investor yang membeli saham perusahaan, maka harga saham perusahaan akan meningkat. Tingginya harga saham suatu perusahaan mencerminkan nilai perusahaan juga tinggi. Berdasarkan uraian tersebut, maka rumusan hipotesis yang dapat diajukan dalam penelitian ini:

$\mathrm{H}_{4}$ : ESOP berpengaruh pada nilai perusahaan secara tidak langsung melalui kinerja perusahaan. 


\section{METODE PENELITIAN}

Penelitian ini dilakukan pada perusahaan yang menerapkan ESOP dan listing atau terdaftar di Bursa Efek Indonesia (BEI) pada tahun 2013-2017 dengan melalui situs resminya www.idx.co.id dan situs resmi perusahaan yang bersangkutan. Variabel dependen dalam penelitian ini adalah nilai perusahaan (Y). Variabel independen dalam penelitian ini adalah ESOP $\left(\mathrm{X}_{1}\right)$.Variabel intervening dalam penelitian ini adalah kinerja perusahaan $\left(\mathrm{X}_{2}\right)$.

Rumus dari Chung dan Pruitt (1994) disesuaikan dengan kondisi keuangan perusahaan di Indonesia dengan tidak menyertakan liquidating value of the firm's outstanding preferred stock (PS) karena pada umumnya perusahaan di Bursa Efek Indonesia tidak menerbitkan saham preferen. Sehinggga rumus Tobin's Q dalam penelitian ini adalah sebagai berikut.

Tobin's $\mathrm{Q}=(\mathrm{MVE}+\mathrm{DEBT}) / \mathrm{TA}$

Keterangan:

MVE = Market Value of Equity

DEBT $=$ Total kewajiban perusahaan

TA $=$ Total aset perusahaan

MVE dihitung dengan mengalikan jumlah saham beredar dengan harga saham. Proporsi opsi saham dapat dihitung dengan rumus sebagai berikut (Dewi, 2018).

Proporsi Opsi Saham = Jumlah Opsi Saham yang Dihibahkan 
ROA dihitung dengan cara membandingkan antara laba bersih setelah pajak dengan total aktiva yang dimiliki perusahaan. ROA dapat dihitung dengan rumus sebagai berikut (Syamsuddin, 2009:63).

ROA $=\quad$ Laba Bersih Setelah Pajak

Total Aktiva Perusahaan

Populasi yang digunakan pada penelitian ini adalah seluruh perusahaan yang terdaftar di Bursa Efek Indonesia (BEI) pada tahun 2013-2017. Sampel pada penelitian ini adalah perusahaan yang terdaftar di Bursa Efek Indonesia (BEI) yang menerapkan ESOP pada tahun 2013-2017 yang sesuai dengan kriteria pemilihan sampel pada penelitian ini.

Teknik analisis data merupakan teknik pengolahan data yang telah dikumpulkan yang nantinya menghasilkan suatu informasi yang digunakan untuk menjawab masalah-masalah yang telah dirumuskan dalam penelitian. Teknik analisis data yang digunakan untuk menyelesaikan masalah-masalah dalam penelitian ini adalah analisis jalur (path analysis). Penyusunan model juga dapat dinyatakan dalam bentuk persamaan diagram jalur yaitu sebagai berikut:

Substruktur 1

$\mathrm{X}_{2}=\mathrm{cX} \mathrm{X}_{1}+\mathrm{e}_{1}$

Substruktur 2

$\mathrm{Y}=\mathrm{aX}+\mathrm{dX}_{2}+\mathrm{e}_{2}$

Keterangan:

$\mathrm{X}_{1} \quad=\mathrm{ESOP}$

$\mathrm{X}_{2} \quad=$ Kinerja Perusahaan

$\mathrm{Y} \quad=$ Nilai Perusahaan

$\mathrm{a}, \mathrm{c}, \mathrm{d}=$ Standardisasi Koefisien Regresi

$\mathrm{Pe}_{1}, \mathrm{Pe}_{2}=$ error 


\section{HASIL DAN PEMBAHASAN}

Pengujian statistik deskriptif digunakan untuk menganalisis data dengan memberikan gambaran atau deskripsi terhadap suatu data mengenai nilai rata-rata (mean), standar deviasi, nilai maksimum, dan nilai minimum dari masing-masing variabel. Hasil dari pengujian statistik deskriptif dalam penelitian ini dapat dilihat pada Tabel 2 sebagai berikut.

Tabel 2.

Hasil Uji Statistik Deskriptif

\begin{tabular}{|c|c|c|c|c|}
\hline & & Proporsi ESOP & ROA & Tobin's Q \\
\hline \multirow[t]{2}{*}{$\mathrm{N}$} & Valid & 48 & 48 & 48 \\
\hline & Missing & 0 & 0 & 0 \\
\hline \multicolumn{2}{|c|}{ Mean } & 0,278831 & 0,032000 & 1,145940 \\
\hline \multicolumn{2}{|c|}{ Std. Error of Mean } & 0,0175604 & 0,0035556 & 0,0478723 \\
\hline \multicolumn{2}{|c|}{ Median } & 0,291700 & 0,035000 & 1,140600 \\
\hline \multicolumn{2}{|c|}{ Mode } & 0,2917 & 0,0350 & 1,2797 \\
\hline \multicolumn{2}{|c|}{ Std. Deviation } & 0,1216619 & 0,0246342 & 0,3316688 \\
\hline \multicolumn{2}{|c|}{ Variance } & 0,015 & 0,001 & 0,110 \\
\hline \multicolumn{2}{|c|}{ Range } & 0,6743 & 0,1543 & 1,9086 \\
\hline \multicolumn{2}{|c|}{ Minimum } & 0,0757 & $-0,0271$ & 0,0943 \\
\hline \multicolumn{2}{|c|}{ Maximum } & 0,7500 & 0,1272 & 2,0029 \\
\hline \multicolumn{2}{|c|}{ Sum } & 13,3839 & 1,5360 & 55,0051 \\
\hline
\end{tabular}

Berdasarkan Tabel 2 diatas, dapat diketahui bahwa jumlah observasi (N) sebanyak 48. Adapun penjelasan statistik deskriptif dari masing-masing variabel penelitian. Employee stock option plan adalah suatu program perusahaan yang memungkinkan para karyawan untuk turut serta memiliki saham dari perusahaan tempat mereka bekerja. Proporsi ESOP memiliki nilai minimal sebesar 0,0757 dan nilai maksimalnya sebesar 0,7500 . Nilai rata-rata (mean) dari proporsi ESOP sebesar 0,278831 dengan standar deviasi 0,1216619, yang artinya bahwa nilai mean lebih besar dari pada standar deviasi, sehingga mengindikasikan hasil yang cukup baik. Hal tersebut karena standar deviasi merupakan pencerminan penyimpangan yang tinggi, sehingga penyebaran data menunjukkan hasil yang 
normal dan tidak menyebabkan bias. Dengan hasil data tersebut menunjukkan bahwa proporsi ESOP memiliki fluktuasi yang kecil karena standar deviasi lebih kecil dibandingkan nilai rata-rata.

Kinerja perusahaan menunjukkan kemampuan perusahaan untuk menghasilkan keuntungan atau pengembalian atas sumber daya yang diinvestasikan di dalamnya. Kinerja Perusahaan diukur dengan ROA. ROA memiliki nilai minimal sebesar -0,0271 dan nilai maksimalnya sebesar 0,1272 . Nilai rata-rata (mean) dari ROA sebesar 0,032000 dengan standar deviasi 0,0246342, yang artinya bahwa nilai mean lebih besar dari pada standar deviasi, sehingga mengindikasikan hasil yang cukup baik. Hal tersebut karena standar deviasi merupakan pencerminan penyimpangan yang tinggi, sehingga penyebaran data menunjukkan hasil yang normal dan tidak menyebabkan bias. Dengan hasil data tersebut menunjukkan bahwa ROA memiliki fluktuasi yang kecil karena standar deviasi lebih kecil dibandingkan nilai rata-rata.

Nilai perusahaan dapat didefinisikan sebagai nilai pasar perusahaan. Nilai perusahaan pada penelitian ini diukur dengan Tobin's Q. Tobin's Q memiliki nilai minimal sebesar 0,0943 dan nilai maksimalnya sebesar 2,0029. Nilai rata-rata (mean) dari Tobin's Q sebesar 1,145940 dengan standar deviasi 0,3316688, yang artinya bahwa nilai mean lebih besar dari pada standar deviasi, sehingga mengindikasikan hasil yang cukup baik. Hal tersebut karena standar deviasi merupakan pencerminan penyimpangan yang tinggi, sehingga penyebaran data menunjukkan hasil yang normal dan tidak menyebabkan bias. Dengan hasil data 
tersebut menunjukkan bahwa Tobin's Q memiliki fluktuasi yang kecil karena standar deviasi lebih kecil dibandingkan nilai rata-rata.

Pengujian data dalam penelitian ini menggunakan analisis jalur (path analysis).Berdasarkan model diagram jalur, persamaan struktural penelitian ini adalah sebagai berikut.

Substruktur 1

$\mathrm{X}_{2}=\mathrm{cX} \mathrm{X}_{1}+\mathrm{e}_{1}$

Substruktur 2

$\mathrm{Y}=\mathrm{aX}+\mathrm{dX}_{2}+\mathrm{e}_{2}$

Pemeriksaan asumsi dalam analisis jalur dilakukan dengan mengamati hubungan antar variabel adalah linier. Model yang telah dibuat harus memiliki hubungan linier atau tanpa adanya hubungan dua arah. Berdasarkan Gambar 2.1, terlihat bahwa hubungan antara variabel adalah linier artinya hubungan variabel independen saling bebas dan tidak ada variabel dependen yang memiliki pengaruh bolak balik.

Koefisien path dibagi menjadi tiga bagian, yaitu koefisien path pengaruh langsung (a), koefisien path pengaruh tidak langsung (c x d), dan pengaruh total $(a+(c x d))$. Hasil perhitungan koefisien path untuk regresi substruktur 1 dan substruktur 2 dapat dilihat pada Tabel 3 dan Tabel 4 sebagai berikut.

Tabel 3.

Hasil Analisis Jalur Regresi Substruktur 1

\begin{tabular}{|c|c|c|c|c|c|c|}
\hline \multirow{2}{*}{\multicolumn{2}{|c|}{ Model }} & \multicolumn{2}{|c|}{$\begin{array}{l}\text { Unstandardized } \\
\text { Coefficients }\end{array}$} & \multirow{2}{*}{$\begin{array}{c}\text { Standardized } \\
\text { Coefficients } \\
\text { Beta }\end{array}$} & \multirow[b]{2}{*}{$\mathrm{t}$} & \multirow[b]{2}{*}{ Sig. } \\
\hline & & $\mathrm{B}$ & Std. Error & & & \\
\hline \multirow[t]{2}{*}{1} & (Constant) & 0,016 & 0,009 & & 1,800 & 0,078 \\
\hline & PROPORSI ESOP & 0,059 & 0,029 & 0,290 & 2,057 & 0,045 \\
\hline
\end{tabular}


Berdasarkan hasil analisis jalur substruktur 1 seperti yang disajikan pada Tabel 3 , maka persamaan strukturalnya adalah sebagai berikut.

$$
\begin{aligned}
& \mathrm{X}_{2}=\mathrm{cX} \mathrm{X}_{1}+\mathrm{e}_{1} \ldots \ldots \\
& \mathrm{X}_{2}=0.290 \mathrm{X}_{1}+\mathrm{e}_{1}
\end{aligned}
$$

\section{Tabel 4.}

Hasil Analisis Jalur Regresi Substruktur 2

\begin{tabular}{llcrrrr}
\hline & \multicolumn{2}{c}{$\begin{array}{c}\text { Unstandardized } \\
\text { Coefficients }\end{array}$} & \multicolumn{2}{c}{$\begin{array}{c}\text { Standardized } \\
\text { Coefficients }\end{array}$} \\
Model & B & Std. Error & Beta & t & \multicolumn{1}{c}{ Sig. } \\
\hline 1 & (Constant) & 0,979 & 0,121 & & 8,092 & 0,000 \\
& PROPORSI & 0,131 & 0,402 & 0,048 & 0,326 & 0,746 \\
& ESOP & & & & & \\
& ROA & 4,067 & 1,987 & 0,302 & 2,046 & 0,047 \\
\hline
\end{tabular}

Sumber:Data diolah, 2018

Berdasarkan hasil analisis jalur substruktur 2 seperti yang disajikan pada

Tabel 4, maka persamaan strukturalnya adalah sebagai berikut.

$$
\begin{aligned}
& Y=a X_{1}+d_{X_{2}}+e_{2} \\
& Y=0.048 X_{1}+0.302 X_{2}+e_{2}
\end{aligned}
$$

Pemeriksaaan validitas model pada analisis jalur dilandasi oleh koefisien determinasi dengan hasil sebagai berikut.Sebelum menghitung nilai $\mathrm{R}^{2} \mathrm{M}$, terlebih dahulu dihitung nilai standard error dengan rumus sebagai berikut.

$$
\begin{aligned}
& \mathrm{Pe}_{\mathrm{i}}=\sqrt{1-\mathrm{R}^{2}} \\
& \mathrm{Pe}_{1}=\sqrt{1-\mathrm{R}^{2}}=\sqrt{1-0,084}=0,957 \\
& \mathrm{Pe}_{2}=\sqrt{1-\mathrm{R}^{2}}=\sqrt{1-0,102}=0,948
\end{aligned}
$$

Maka, nilai koefisien determinasi total $\left(\mathrm{R}^{2} \mathrm{M}\right)$ adalah sebagai berikut.

$$
\begin{aligned}
& \mathrm{R}^{2} \mathrm{M}=1-\left(\mathrm{Pe}_{1}\right)^{2}\left(\mathrm{Pe}_{2}\right)^{2} \ldots\left(\mathrm{Pe}_{\mathrm{p}}\right)^{2} \\
& \mathrm{R}^{2} \mathrm{M}=1-\left(\mathrm{Pe}_{1}\right)^{2}\left(\mathrm{Pe}_{2}\right)^{2} \\
& \mathrm{R}^{2} \mathrm{M}=1-\left((0,957)^{2}(0,948)^{2}\right)
\end{aligned}
$$


$\mathrm{R}^{2} \mathrm{M}=0,177$

Koefisien determinasi total sebesar 0,177 mempunyai arti bahwa sebesar 17,7 persen informasi yang terkandung dapat dijelaskan oleh model yang dibentuk, sedangkan sisanya yaitu 82,3 persen dijelaskan oleh variabel lain diluar model yang dibentuk.

Tabel 5.

Pengaruh Langsung dan Pengaruh Tidak Langsung serta Pengaruh Total ESOP $\left(X_{1}\right)$, Kinerja Perusahaan $\left(X_{2}\right)$, dan Nilai Perusahaan $(Y)$

\begin{tabular}{|c|c|c|c|c|}
\hline Peng & aruh Variabel & $\begin{array}{l}\text { Pengaruh } \\
\text { Langsung } \\
\text { (a) }\end{array}$ & $\begin{array}{c}\text { Pengaruh Tidak } \\
\text { Langsung (melalui } \\
\text { Kinerja Perusahaan) } \\
\text { (c x d) }\end{array}$ & $\begin{array}{c}\text { Pengaruh Total } \\
(a+(c \times d))\end{array}$ \\
\hline $\begin{array}{l}\text { ESOP } \\
\text { ESOP } \\
\text { KP }\end{array}$ & $\begin{array}{l}\longrightarrow \mathrm{NP} \\
\longrightarrow \mathrm{KP} \\
\longrightarrow \mathrm{NP}\end{array}$ & $\begin{array}{l}a=0,048 \\
c=0,290 \\
d=0,302\end{array}$ & 0,08758 & $\begin{array}{l}0,13558 \\
0,290 \\
0,302\end{array}$ \\
\hline
\end{tabular}

Sumber: Data Diolah, 2018

Berdasarkan hasil pemeriksaan validitas model diatas, dapat diketahui bahwa pengaruh ESOP $\left(\mathrm{X}_{1}\right)$ pada Kinerja Perusahaan $\left(\mathrm{X}_{2}\right)$ memiliki nilai signifikansi atau sig t sebesar 0,045 . Nilai sig t $0,045<0,05$ menunjukkan bahwa terdapat pengaruh langsung antara variabel independen dan variabel mediasi.

Pengaruh Kinerja Perusahaan $\left(\mathrm{X}_{2}\right)$ pada Nilai Perusahaan $(\mathrm{Y})$ memiliki nilai signifikansi atau sig t sebesar 0,047 . Nilai sig $\mathrm{t} 0,047<0,05$ menunjukkan bahwa terdapat pengaruh langsung antara variabel mediasi dengan variabel dependen.

Pengaruh ESOP $\left(\mathrm{X}_{1}\right)$ pada Nilai Perusahaan (Y) memiliki nilai signifikansi atau sig t sebesar 0,746 . Nilai sig t $0,746>0,05$, maka tidak terdapat pengaruh langsung antara variabel independen dengan variabel dependen.

Pengujian hipotesis pengaruh langsung tidak langsung mengacu pada penelitian yang dilakukan oleh Solimun (2010). Pemeriksaan atas adanya 
pengaruh mediasi menggunakan metode pemeriksaan dengan cara melakukan dua kali analisis, yaitu analisis dengan melibatkan variabel mediasi dan analisis tanpa melibatkan variabel mediasi. Hasil perhitungan sebelumnya didapat nilai koefisien $\mathrm{a}=0,048(\operatorname{sig} \mathrm{a}=0,746)$, nilai koefisien $\mathrm{c}=0,290(\operatorname{sig} \mathrm{c}=0,045)$, dan nilai koefisien $\mathrm{d}=0,302(\operatorname{sig} \mathrm{d}=0,047)$. Berdasarkan hasil tersebut maka kinerja perusahaan dikatakan sebagai variabel mediasi sempurna (complete mediation), karena nilai (c) signifikan dan (d) signifikan, tetapi nilai (a) tidak signifikan. Ini berarti bahwa kinerja perusahaan mampu memediasi hubungan ESOP pada nilai perusahaan.

Hipotesis pertama $\left(\mathrm{H}_{1}\right)$ dalam penelitian ini menyatakan bahwa ESOP berpengaruh positif pada kinerja perusahaan. Berdasarkan hasil analisis jalur yang telah ditunjukkan pada Tabel 3, menunjukkan bahwa koefisien regresi standar sebesar 0,290 dengan tingkat signifikansi sebesar 0,045 lebih kecil dari 0,05. Hasil ini berarti $\mathrm{H}_{0}$ ditolak dan $\mathrm{H}_{1}$ diterima, sehingga dapat disimpulkan bahwa ESOP berpengaruh positif pada kinerja perusahaan. Hal ini menunjukkan bahwa semakin tinggi jumlah ESOP maka kinerja perusahaan juga akan semakin meningkat.

Dengan adanya ESOP karyawan akan memiliki rasa sense of belonging sehingga akan termotivasi untuk meningkatkan kinerjanya. Peningkatan kinerja karyawan akan berdampak pada peningkatan kinerja perusahaan. Opsi yang melibatkan seluruh karyawan diharapkan dapat menjadi suatu motivator yang lebih efektif untuk meningkatkan kinerja perusahaan dibandingan suatu bonus kas. Karena tidak seperti kas, opsi terus menerus berlaku sebagai suatu insentif 
yang baik bagi karyawan setelah mereka diberikan opsi, karena nilai sebenarnya akan ditentukan dengan kinerja perusahaan dimasa yang akan datang. Kinerja karyawan yang meningkat akan berdampak pada meningkatnya kinerja perusahaan.

Hasil penelitian ini sejalan dengan penelitian yang dilakukan olehNgambi dan Oloume (2013), (Astika, 2005), dan Han dan Shen (2007) menyatakan bahwa perusahaan yang melaksanakan ESOP memiliki kinerja yang lebih tinggi dibandingkan yang tidak melaksanakan ESOP. Selain itu penelitian yang dilakukan oleh Sesil et al., (2002) dan Iqbal dan Hamid (2000) juga menemukan bahwa ESOP berpengaruh terhadap kinerja perusahaan. Menurut Pugh et al., (2000), pengumuman ESOP mampu meningkatkan motivasi kerja karyawan dan ternyata menimbulkan perbedaan antara periode sebelum pengumuman ESOP dengan periode setelah pengumuman ESOP.

Hipotesis kedua $\left(\mathrm{H}_{2}\right)$ dalam penelitian ini menyatakan bahwa kinerja perusahaan berpengaruh positif pada nilai perusahaan. Berdasarkan hasil analisis jalur yang telah ditunjukkan pada Tabel 5, menunjukkan bahwa koefisien regresi standar sebesar 0,302 dengan tingkat signifikansi sebesar 0,047 lebih kecil dari 0,05. Hasil ini berarti $\mathrm{H}_{0}$ ditolak dan $\mathrm{H}_{2}$ diterima, sehingga dapat disimpulkan bahwa kinerja perusahaan berpengaruh positif pada nilai perusahaan. Hal ini menunjukkan bahwa semakin tinggi kinerja perusahaan maka nilai perusahaan juga akan semakin meningkat.

Kinerja perusahaan merupakan aspek penting yang dilihat oleh para investor untuk menilai kondisi perusahaan di masa kini dan juga prospek 
perusahaan di masa depan. Investor yang ingin menanamkan sahamnya seringkali melihat kinerja perusahaan sebagai pertimbangan dalam memutuskan dana yang diinvestasikan. Apabila kinerja suatu perusahaan dilihat baik, maka investor akan menganggap bahwa prospek suatu perusahaan tersebut baik sehingga menyebabkan investor tertarik untuk menginvestasikan dana yang dimilikinya pada perusahaan tersebut.

Hasil penelitian ini sejalan dengan penelitian yang dilakukan oleh Prapaska dan Mutmainah (2012), Anzalina dan Rustam (2013), dan Yuniasih dan Wirakusuma, (2009) menemukan bahwa kinerja perusahaan berpengaruh positif terhadap nilai perusahaan.Selain itu penelitian yang dilakukan oleh Ulupui (2007) dan Nurhayati (2013), juga membuktikan bahwa ROA berpengaruh positif terhadap nilai perusahaan. Menurut Hermuningsih (2013), apabila ROA meningkat, maka investor dapat menangkap sinyal positif dari manajemen perusahaan sehingga memudahkan manajemen menarik modal dalam bentuk saham.

Hipotesis ketiga $\left(\mathrm{H}_{3}\right)$ dalam penelitian ini menyatakan bahwa ESOP berpengaruh positif pada nilai perusahaan. Berdasarkan hasil analisis jalur yang telah ditunjukkan pada Tabel 4, menunjukkan bahwa koefisien regresi standar sebesar 0,048 dengan tingkat signifikansi sebesar 0,746 lebih besar dari 0,05. Hasil ini berarti $\mathrm{H}_{3}$ ditolak dan $\mathrm{H}_{0}$ diterima, sehingga dapat disimpulkan bahwa ESOP tidak berpengaruh pada nilai perusahaan.

Pengadopsian ESOP yang dianggap mampu untuk meningkatkan nilai pasar saham perusahaan ternyata tidak menimbulkan perbedaan antara periode 
Ni Wayan Dea Darmala dan Ni Gusti Putu Wirawati. Pengaruh ...

sebelum pengadopsian ESOP dengan periode sesudah pengadopsian ESOP. Hal ini berarti ESOP tidak dipandang oleh investor sebagai faktor yang mampu meningkatkan nilai perusahaan. Sehingga, ketika perusahaan mengumumkan ESOP, investor tidak menangkap sinyal pengumuman tersebut sebagai good news sehingga harga pasar saham perusahaan tidak meningkat akibat dari adanya pengumuman ESOP.

Hasil penelitian ini sejalan dengan penelitian yang dilakukan oleh Qureyta (2016) yang menyatakan bahwa PBV yang merupakan pengukuran nilai perusahaan sesudah penerapan ESOP tidak lebih baik daripada sebelum penerapan ESOP. Hasil penelitian ini diperkuat oleh penelitian yang dikemukakan oleh Setyaningrum (2012) yang menemukan bahwa tidak adanya pengaruh pengadopsian ESOP terhadap PBV perusahaan sebelum pengadopsian ESOP dan sesudah pengadopsian ESOP.

Hipotesis keempat $\left(\mathrm{H}_{4}\right)$ dalam penelitian ini menyatakan bahwa ESOP berpengaruh pada nilai perusahaan secara tidak langsung melalui kinerja perusahaan. Pengujian hipotesis keempat mengacu pada model yang digunakan oleh (Solimun, 2010). Berdasarkan hasil perhitungan didapatkan nilai koefisien a $=0,048(\operatorname{sig} \mathrm{a}=0,746)$, nilai koefisien $\mathrm{c}=0,290(\operatorname{sig} \mathrm{c}=0,045)$, dan nilai koefisien $\mathrm{d}=0,302$ ( $\operatorname{sig} \mathrm{d}=0,047$ ). Berdasarkan hasil tersebut maka kinerja perusahaan dikatakan sebagai variabel mediasi sempurna (complete mediation), karena nilai (c) signifikan dan (d) signifikan, tetapi nilai (a) tidak signifikan. Ini berarti bahwa ESOP berpengaruh pada nilai perusahaan melalui kinerja 
perusahaan. Semakin tinggi ESOP, maka akan menyebabkan tingginya kinerja perusahaan sehingga nilai perusahaan juga akan meningkat.

Dengan adanya ESOP, maka karyawan akan memiliki sense of belonging terhadap perusahaan sehingga menjadi lebih termotivasi untuk meningkatkan kinerjanya. Peningkatan kinerja karyawan akan berdampak pula pada peningkatan kinerja perusahaan. Perusahaan dengan kinerja keuangan yang baik, tentunya akan diminati oleh investor sehingga membuat investor percaya dan menanamkan modalnya pada perusahaan. Semakin banyak investor yang membeli saham perusahaan, maka harga saham perusahaan akan meningkat. Tingginya harga saham suatu perusahaan mencerminkan nilai perusahaan juga tinggi. Sehingga dapat dikatakan bahwa kinerja perusahaan mampu memediasi hubungan ESOP pada nilai perusahaan.

Penelitian ini menghasilkan simpulan mengenai bagaimana pengaruh ESOP pada nilai perusahaan dengan kinerja perusahaan sebagai variabel mediasi. Hasil dari penelitian ini menunjukkan bahwa ESOP berpengaruh positif pada kinerja perusahaan, kinerja perusahaan berpengaruh positif pada nilai perusahaan, ESOP tidak berpengaruh pada nilai perusahaan, dan ESOP berpengaruh tidak langsung pada nilai perusahaan melalui kinerja perusahaan. Penelitian ini diharapkan dapat digunakan untuk memberikan pengembangan pengetahuan dalam bidang ilmu akuntansi khususnyamengenai pengaruh pemberianEmployee Stock Option Plan (ESOP) pada kinerja perusahaan dan implikasinya terhadap nilai perusahaan. 
Penelitian ini sejalan dengan teori keagenan yang menjelaskan hubungan antara principal sebagai pemilik perusahaan dan agent sebagai pengelola perusahaan dapat mengarah pada adanya konflik keagenan akibat ketidakseimbangan informasi sehingga salah satu cara untuk mengurangi konflik keagenan adalah dengan mengadakan program ESOP. Dengan adanya program ESOP, maka karyawan mendapatkan kesempatan untuk memiliki saham perusahaan tempat mereka bekerja sehingga tumbuh rasa memiliki terhadap perusahaan .

Penelitian ini juga sejalan dengan teori sinyal yang menyatakan bahwa suatu pesan atau kejadian yang merupakan sinyal yang diberikan perusahaan kepada pasar dikatakan mengandung informasi apabila pesan tersebut mengakibatkan perubahan keyakinan penerima dan memicu tindakan tertentu. Pada penelitian ini, peningkatan kinerja perusahaan yang diproxikan dengan ROA mampu menjadi sinyal yang positif (good news) bagi pasar sehingga investor bereaksi untuk membeli saham perusahaan tersebut. Banyaknya investor yang tertarik untuk menanamkan sahamnya akan menyebabkan harga saham perusahaan meningkat sehingga investor memandang nilai perusahaan tersebut tinggi.

Penelitian ini diharapkan dapat memberikan manfaat bagi pihak-pihak yang berkepentingan seperti perusahaan dan Investor. Bagi perusahaan,hasil penelitian inidiharapkan dapat memberikan manfaat dan masukan terkait dengan kebijakan ESOP yang dilakukan dan dapat digunakan sebagai bahan pertimbangan dalam pengambilan keputusan bagi perusahaan. Serta bagi investor, 
hasil penelitian ini diharapkan dapat menjadi bahan pertimbangan bagi investor untuk melakukan keputusan investasi dan menambah informasi bagi investor sehingga dapat meminimalkan resiko yang nanti akan ditanggungnya.

\section{SIMPULAN}

ESOP berpengaruh positif pada kinerja perusahaan. Ini menunjukkan bahwa semakin tinggi jumlah ESOP maka kinerja perusahaan juga akan semakin meningkat. Dengan adanya ESOP karyawan akan memiliki rasa sense of belonging sehingga akan termotivasi untuk meningkatkan kinerjanya. Peningkatan kinerja karyawan akan berdampak pada peningkatan kinerja perusahaan.

Kinerja perusahaan berpengaruh positif pada nilai perusahaan. Hal ini menunjukkan bahwa semakin tinggi kinerja perusahaan maka nilai perusahaan juga akan semakin meningkat. Apabila kinerja suatu perusahaan dilihat baik, maka investor akan menganggap bahwa prospek suatu perusahaan tersebut baik sehingga menyebabkan investor tertarik untuk menginvestasikan dana yang dimilikinya pada perusahaan tersebut dan menyebabkan nilai perusahaan meningkat.

ESOP tidak berpengaruh pada nilai perusahaan. Hal ini berarti ESOP tidak dipandang oleh investor sebagai faktor yang mampu meningkatkan nilai perusahaan. Sehingga, ketika perusahaan mengumumkan ESOP, investor tidak menangkap sinyal pengumuman tersebut sebagai good news sehingga harga pasar saham perusahaan tidak meningkat akibat dari adanya pengumuman ESOP. 
ESOP berpengaruh pada nilai perusahaan secara tidak langsung melalui kinerja perusahaan. Hal ini berarti semakin tinggi ESOP, maka akan menyebabkan tingginya kinerja perusahaan sehingga nilai perusahaan juga akan meningkat.

Bagi perusahaan, diharapkan semakin banyak perusahaan yang menerapkan program ESOP ini karena telah terbukti mampu untuk memotivasi karyawan untuk turut serta dalam meningkatkan kinerja perusahaan sehingga nilai perusahaan juga semakin meningkat dan investor sebagai pemegang saham mendapatkan kesejahteraan melalui program ESOP ini.

Bagi Investor, dalam mempertimbangkan keputusan untuk berinvestasi sebaiknya melihat sinyal dari pengumuman ESOP ini sebagai good news karena dengan adanya program ESOP, investor mendapat gambaran bahwa prospek perusahaan tersebut kedepannya akan baik.

Bagi peneliti selanjutnya, diharapkan dapat memperpanjang periode waktu yang digunakan dalam penelitian karena hal ini mungkin akan mempengaruhi hasil penelitian.

\section{REFERENSI}

Anwar, A., \& Baridwan, Z. (2006). Effect of Employee Stock Option Plans (ESOPS) to Performance and Firm Value: Empirical Study at JSX. Simposium Nasional Akuntansi 9 Padang Padang, 1-20.

Anzalina, C. W., \& Rustam. (2013). Pengaruh Tingkat Likuiditas, Solvabilitas, Aktivitas, dan Profitabilitas Terhadap Nilai Perusahaan Real Estate dan Property di BEI Tahun 2006-2008. Jurnal Ekonom, 16(2), 67-75.

Aribawa, D. (2016). Analisis Nilai Perusahaan pada Implementasi Program Kepemilikan Saham pada Karyawan/Manajemen. Jurnal Ekonomi Dan 
Bisnis, 19(3), 341-353.

Astika, I. B. P. (2005). Manfaat dan Faktor-faktor yang Berpengaruh terhadap Pengadopsian Program Opsi Saham pada Perusahaan Publik yang Listing di Bursa Efek Jakarta. Jurnal Ilmiah Akuntansi Dan Bisnis, 2(2), 58-67.

Astika, I. B. P. (2012). Harga Referensi dan Return Expectation dalam Employee Stock Of Option Plan. Finance and Banking Journal, 14(1), 89-99.

Bacha, O. I., Raihan, S., Rasid, M., \& Mohd, A. (2009). Granting Employee Stock Options (ESOs), Market Reaction and Financial Performance. Asian Academy of Management Journal of Accounting and Finance, 5(1), 117138.

Borstadt, L. F., \& Zwirlein, T. J. (1995). ESOPS in Publicly Held Companies: Evidence on Productivity and Firm Performance. Journal of Financial and Strategic Decisions, 8(1), 1-15.

Brigham, E. ., \& Gapenski, L. (1996). Intermadiate Finance Management (5th ed.). Harbor Drive: The Dryden Press.

Chung, K. H., \& Pruitt, S. W. (1994). A Simple Approximation of Tobin's q. Financial Management, 23(3), 70. https://doi.org/10.2307/3665623

Dewi, G. A. (2018). Pengaruh Pemberian Employee Stock Option Program Terhadap Kinerja Perusahaan dengan Struktur Modal Sebagai Variabel Moderasi. E-Jurnal Akuntansi Universitas Udayana, 22(3), 1857-1881.

Eisenhardt, K. M. (1989). Agency Theory: and Assessment Review. The Academy of Management Review, 14(1), 57-74.

Fama, E. F. (1978). The effects of a firm's investment and financing decisions on the welfare of its security holders. American Economic Review, 68(3), 272-284. https://doi.org/10.2307/1805260

Han, T. S., \& Shen, C. H. (2007). The effects of bonus systems on firm performance in Taiwan's high-tech sector. Journal of Comparative Economics, 35(1), 235-249. https://doi.org/10.1016/j.jce.2006.09.002

Herawati, T. (2013). Pengaruh Kebijakan Deviden, Kebijakan Hutang dan Profitabilitas terhadap Nilai Perusahaan. Jurnal Universias Negeri Padang, 2(2), 1-18.

Herdinata, C. (2012). Reaksi Pasar terhadap Pengumuman Employee Stock Ownership Program. Jurnal Keuangan Dan Perbankan, 16(1), 77-85. 
Hermuningsih, S. (2013). Pengaruh Profitabilitas, Growth Opportunity, Sruktur Modal Terhadap Nilai Perusahaan Pada Perusahaan Publik di Indonesia. Buletin Ekonomi Moneter Dan Perbankan, 127-148.

Iqbal, Z., \& Hamid, S. A. (2000). Stock Price and Operating Performance of ESOP Firms: A Time-Series Analysis. Quarterly Journal of Business and Economics, 39(3), 25-47.

Letlora, S. C. (2012). Pengaruh Pengumuman Employee Stock Option Program terhadap Reaksi Pasar dan Kinerja Perusahaan pada Perusahaan Publik yang Terdaftar di Bursa Efek Indonesia. Journal of Business and Banking, 2(2), 227-240.

Ngambi, M. T., \& Oloume, F. (2013). Employee Share Ownership and Firm Performance: Evidance From A Sample of Cameroonian Firms. International Journal of Research in Social Sciences, 2(3), 48-55.

Nurhayati, M. (2013). Profitabilitas, Likuiditas dan Ukuran Perusahaan Pengaruhnya terhadap Kebijakan Dividen dan Nilai Perusahaan Sektor Non Jasa. Jurnal Keuangan Dan Bisnis, 5(2), 144-153.

Panggabean, S. M. (2004). Manajemen Sumber Daya Manusia. Bogor: Ghalia Indonesia.

Poornima, D. ., Kala, K. N., \& Kala, D. . V. (2015). Impact of Employee Stock Options on Corporate Performance with Special Reference to Selected Financial Services Companies in India. Journal of Research in Management, Social Sciences and Technology, 9(9), 1-5.

Prapaska, J. R., \& Mutmainah, S. (2012). Analisis Pengaruh Profitabilitas, Keputusan Investasi, Keputusan Pendanaan dan Kebijakan Deviden terhadap Nilai Perusahaan pada Perusahaan Manufaktur di BEI Tahun 2009-2010. Diponegoro Journal of Accounting, 1(1), 1-12.

Pugh, W. N., Oswald, S. L., \& Jahera, J. S. (2000). The effect of ESOP adoptions on corporate performance: are there really performance changes? Journal of Managerial and Decision Economics, 21(5), 167-180. https://doi.org/10.1002/mde.971

Putri, I. F., \& Nasir, M. (2006). Simposium nasional akuntansi 9 padang analisis persamaan simultan kepemilikan manajerial, kepemilikan Analisis Persamaan Simultan Kepemilikan Manajerial, Kepemilikan Institusional, Risiko, Kebijakan Hutang dan Kebijakan Dividen dalam Perspektif Teori Keag. Simposium Nasional Akuntansi 9 Padang, 1-25. 
Qureyta, H. D. (2016). Pengaruh Kebijakan Employee Stock Ownership Program terhadap Perkembangan Kinerja Keuangan dan Kinerja Pasar Perusahaan yang Terdaftar di Bursa Efek Indonesia. STIE Perbanas Surabaya, 1-17.

Rachmawati, A., \& Triatmoko, H. (2007). Analisis Faktor-faktor yang Mempengaruhi Kualitas Laba dan Nilai Perusahaan. Simposium Nasional Akuntansi X, 1-26.

Sesil, J. C., Kroumova, M. K., Blasi, J. R., \& Kruse, D. L. (2002). Broad-based Employee Stock Options in US 'New Economy' Firms. British Journal of Industrial Relations, 40(2), 273-294. https://doi.org/10.1111/14678543.00232

Setyaningrum, A. N. (2012). Pengaruh Employee Stock Option Ownership Program (ESOP) terhadap Kualitas Implementasi Corporate Governance dan Kinerja Perusahaan. Jurnal Ilmiah Mahasiswa FEB Universitas Brawijaya, 1(1).

Solimun. (2010). Analisis Multivariat Pemodelan Struktural Metode Partial Least Square-PLS. Malang: CV Citra.

Sukamulja, S. (2002). Good Corporate Governance di Sektor Keuangan: Dampak GCG terhadap Kinerja Perusahaan (Kasus di Bursa Efek Jakarta). BENEFIT, 8(1), 1-25.

Susilowati, Y. (2011). Reaksi Signal Rasio Profitabilitas dan Rasio Solvabilitas terhadap Return Saham Perusahaan. Dinamika Keuangan Dan Perbankan, 3(1), 17-37.

Syamsuddin. (2009). Manajemen Keuangan Perusahaan. Jakarta: PT. Raja Grafindo Persada.

Triagustina, L., Sukarmanto, E., \& Helliana. (2012). Pengaruh Return On Asset (ROA) dan Return On Equity (ROE) terhadap Nilai Perusahaan pada Perusahaan Manufaktur Subsektor Makanan dan Minuman yang Terdaftar di Bursa Efek Indonesia Periode 2010-2012. Prosiding Akuntansi, 28-34.

Ulupui, I. G. K. . (2007). Analisis Pengaruh Rasio Likuiditas, Leverage, Aktivitas, dan Profitabilitas terhadap Return Saham (Studi pada Perusahaan Makanan dan Minuman dengan Kategori Industri Barang Konsumsi di BEJ). Jurnal Ilmiah Akuntansi Dan Bisnis, 2(1), 1-20.

Wahyudi, U., \& Pawestri, H. P. (2006). Implikasi Struktur Kepemilikan terhadap Nilai Perusahaan: Dengan Keputusan Keuangan Sebagai Variabel Intervening. Simposium Nasional Akuntansi 9 Padang, 1-25. 
Yeo, G. H. H., Chen, S.-S., Ho, K. W., \& Lee, C. (1999). Effects of Executive Share Option Plans on Shareholder Wealth and Firm Performance: The Singapore Evidence. The Financial Review, 34(2), 1-20. https://doi.org/10.1111/j.1540-6288.1999.tb00451.x

Yuniasih, N. W., \& Wirakusuma, M. G. (2009). Pengaruh Kinerja Keuangan terhadap Nilai Perusahaan dengan Pengungkapan Corporate Social Responsibility dan Good Corporate Governance sebagai Variabel Pemoderasi. Jurnal Ilmiah Akuntansi Dan Bisnis, 4(1), 1-10. 